\title{
CORROSION STUDIES OF TITANIUM IN BORATED WATER FOR TPX
}

\author{
The submitted manuscript has been \\ authored by, a contractor of the U.S. \\ Government under contract No. DE- \\ ACO5-84OA2 1400. Accordingly, the U.S. \\ Government retains a nonexclusive, \\ royalty-free license to publish or reproduce \\ the published form of this contribution, of \\ allow others to do so, for U.S. Government \\ purpases."
}

RECFUVE

FEB 05 MSO

Oak Ridge National Laboratory

Oak Ridge, Tennessee 37831-6156

\section{ABSTRACT}

Corrosion testing was performed to demonstrate the compatibility of the titanium vacuum vessel with borated water. Borated water is proposed to fill the annulus of the double wall vacuum vessel to provide effective radiation shielding. Borating the water with 110 grams of boric acid per liter is sufficient to reduce the nuclear heating in the Toroidal Field Coil set and limit the activation of components external to the vacuum vessel. Constant extension rate tensile (CERT) and electrochemical potentiodynamic tests were performed.

Results of the CERT tests confirm that stress corrosion cracking is not significant for Ti-6Al-4V or Ti-3Al-2.5V. Welded and unwelded specimens were tested in air and in borated water at $150^{\circ} \mathrm{C}$. Strength, elongation, and time to failure were nearly identical for all test conditions, and all the samples exhibited ductile failure.

Potentiodynamic tests on Ti-6Al-4V and Ti in borated water as a function of temperature showed low corrosion rates over a wide passive potential range. Further, this passivity appeared stable to anodic potentials substantially greater than those expected from MHD effects.

\section{INTRODUCTION}

Corrosion tests of titanium alloys were performed in support of the Tokamak Physics Experiment (TPX). TPX, proposed as the next major tokamak device in the U.S. Fusion Program, has as its mission the development of a scientific basis for a compact and continuously operating Tokamak Fusion Reactor. Operating TPX with deuterium fuel will result in fusion reactions that produce significant neutron flux. A double-wall titanium vacuum vessel has been proposed to limit the nuclear heating of the superconducting coil set and the activation of components outside of the shield. Borated water, 110 grams of boric acid per liter, will fill the annulus of the double-wall vessel to provide effective radiation shielding. It was originally proposed that the vessel and borated water would be maintained at $150^{\circ} \mathrm{C}$.

Testing of titanium alloys in borated water was performed to demonstrate the compatibility of the titanium vessel with hot borated water under system induced changing potentials. Two alloys were tested; Ti-6Al-4V, candidate material for the vessel structure and Ti-3AI-2.5V, candidate material for the connecting pipe.

\section{EXPERIMENTAL}

Two types of tests, constant extension rate tensile (CERT) tests, and electrochemical tests were performed. CERT tests were used to evaluate the susceptibility of titanium exposed in borated water to stress corrosion cracking. Electrochemical tests were used to evaluate the effect of magnetohydrodynamic (MHD) induced potentials on the corrosion rate of titanium.

CERT tests were performed on as-received and welded (gas tungsten arc) specimens in concentrated boric acid solutions $(110 \mathrm{~g} / /)$ at $150^{\circ} \mathrm{C}$ in a Hastelloy $\mathrm{C}$ autoclave. The tensile specimens were strained along their longitudinal axes at rates $\leq 2 \times 10^{-6} \mathrm{~s}^{-1}$. The test solution was sparged with either argon gas (deaeration) or filtered air (aeration) prior to start of the experiments.

Polarization curves were developed for as-received rod specimens of titanium (Ti) and Ti-6Al-4V. Curves were developed in solutions of saturated boric acid $(110 \mathrm{~g} /)$ at room temperature and at boiling (about $104^{\circ} \mathrm{C}$ ). In each case, solutions were open to air under an Allihn-type condenser. The potentials scanned ranged from the open circuit potential of the test material to a value about 2.5 volts positive to this value. Various potential scan rates were employed.

Research sponsored by the Office of Fusion Energy, U. S. Department of Energy, under contract DE-AC05-84OR21400 with Lockheed Martin Energy Systems, Inc. 
Ti-6Al-4V was procured in the form of a $1 / 2$-in $(12.7 \mathrm{~mm})$ bar and conformed to ASTM specification B-348, Grade 5. This material had been heat treated for $2-\mathrm{h}$ at $704^{\circ} \mathrm{C}$. Ti-3A-2.5V was procured in the form of $1 / 2-i n(12.7 \mathrm{~mm}) \times$ 0.049-in $(1.2 \mathrm{~mm})$ tubing and conformed to AMS specification 4943D. This material had been heat treated for $2-h$ at $649^{\circ} \mathrm{C}$. The vendor supplied chemical analyses of these materials are presented in Table 1. Composition of the filler metal was the same as that of the metal being welded. All welds were made in an argon-filled glove box with oxygen and water impurities maintained at less than 1 and $10 \mathrm{ppm}$ (by volume), respectively.

Table 1. Chemical composition of alloys in weight percent.

\begin{tabular}{lcc}
\hline Element & Ti-6Al-4V & Ti-3Al-2.5V \\
\hline Aluminum & 6.22 & 2.98 \\
Vanadium & 4.11 & 2.48 \\
Iron & 0.22 & 0.14 \\
Carbon & 0.01 & 0.01 \\
Oxygen & 0.19 & 0.09 \\
Nitrogen & 0.02 & 0.006 \\
Yttrium & $<0.001$ & $<0.005$ \\
Hydrogen & 0.004 & 0.0018 \\
Titanium & balance & balance
\end{tabular}

\section{Results}

Results of the CERT tests for Ti-6Al-4V are presented in Table 2. All specimens exhibited cup-cone fracture surfaces and no evidence of surface cracking was observed.

Table 2. Test results for un-welded Ti-6Al-4V specimens (from $1 / 2$-in bar).

\begin{tabular}{ccccc}
\hline $\begin{array}{c}\text { Test } \\
\text { Condition }\end{array}$ & $\begin{array}{c}\text { Extension } \\
\text { Rate }\left(\mathrm{s}^{-1}\right)\end{array}$ & $\begin{array}{c}\text { Time to } \\
\text { Failure }(\mathrm{h})\end{array}$ & $\begin{array}{c}\text { Elongation } \\
(\%)\end{array}$ & $\begin{array}{c}\text { Ultimate } \\
\text { Strength } \\
\text { (MPa) }\end{array}$ \\
\hline A & $1.14 \mathrm{E}-06$ & 26.9 & 11.0 & 919 \\
A & $1.98 \mathrm{E}-06$ & 19.0 & 13.3 & 976 \\
B & $1.14 \mathrm{E}-06$ & 30.5 & 12.4 & 917 \\
C & $1.37 \mathrm{E}-06$ & 24.6 & 12.1 & 922 \\
\hline
\end{tabular}

A) Borated water at $150^{\circ} \mathrm{C}$; de-aerated

B) Borated water at $150^{\circ} \mathrm{C}$; aerated

C) Air atmosphere at $150^{\circ} \mathrm{C}$

Results of the CERT tests for Ti-6AI-4V specimens welded at Oak Ridge National Laboratory and at McDonnell Douglas Corporation are presented in Tables 3 and 4 .
Visual inspection of specimens in Table 3 showed that deformation, as measured by reduction in cross-sectional area, was confined exclusively to the relatively narrow weld fusion zone.

Table 3. Test results for ORNL welded (GTAW) Ti-6Al-4V specimens (from $1 / 2$-in bar).

\begin{tabular}{ccccc}
\hline $\begin{array}{c}\text { Test } \\
\text { Condition }\end{array}$ & $\begin{array}{c}\text { Extension } \\
\text { Rate }\left(\mathrm{s}^{-1}\right)\end{array}$ & $\begin{array}{c}\text { Time to } \\
\text { Failure }(\mathrm{h})\end{array}$ & $\begin{array}{c}\text { Elongation } \\
(\%)\end{array}$ & $\begin{array}{c}\text { Ultimate } \\
\text { Strength } \\
(\mathrm{MPa})\end{array}$ \\
\hline B & $1.14 \mathrm{E}-06$ & 5.9 & 2.4 & 751 \\
B & $1.14 \mathrm{E}-06$ & 18.2 & 7.5 & 791 \\
B & $1.11 \mathrm{E}-06$ & 8.9 & 3.7 & 692 \\
C & $1.37 \mathrm{E}-06$ & 5.2 & 2.6 & 683 \\
C & $1.34 \mathrm{E}-06$ & 11.7 & 5.6 & 732 \\
\hline
\end{tabular}

B) Borated water at $150^{\circ} \mathrm{C}$; aerated

C) Air atmosphere at $150^{\circ} \mathrm{C}$

Table 4. Test results for McDonnell Douglas welded (GTAW) Ti-6Al-4V specimens (from $1 / 2$-in plate).

\begin{tabular}{ccccc}
\hline $\begin{array}{c}\text { Test } \\
\text { Condition }\end{array}$ & $\begin{array}{c}\text { Extension } \\
\text { Rate }\left(\mathrm{s}^{-1}\right)\end{array}$ & $\begin{array}{c}\text { Time to } \\
\text { Failure }(\mathrm{h})\end{array}$ & $\begin{array}{c}\text { Elongation } \\
(\%)\end{array}$ & $\begin{array}{c}\text { Ultimate } \\
\text { Strength } \\
\text { (MPa) }\end{array}$ \\
\hline $\mathrm{B}^{*}$ & $1.11 \mathrm{E}-06$ & 20.2 & 8.2 & 760 \\
$\mathrm{~B}^{*}$ & $1.11 \mathrm{E}-06$ & 19.9 & 8.1 & 761 \\
$\mathrm{C}^{*}$ & $1.34 \mathrm{E}-06$ & 16.0 & 7.7 & 742 \\
McD & & & 12.0 & $794^{\dagger}$ \\
unwelded & & & & \\
\hline
\end{tabular}

B) Borated water at $150^{\circ} \mathrm{C}$; aerated

C) Air atmosphere at $150^{\circ} \mathrm{C}$

${ }^{\dagger} 0.8$ (UTS) $=0.8(993)$; corrected for test temperature difference

"Specimen from outer edge of plate; "Specimen from center of plate

Results of the CERT test for Ti-3Al-2.5V specimens are presented in Table 5.

Table 5. Test results for Ti-3Al-2.5V specimens (from $1 / 2$-in tube).

\begin{tabular}{ccccc}
\hline $\begin{array}{c}\text { Test } \\
\text { Condition }\end{array}$ & $\begin{array}{c}\text { Extension } \\
\text { Rate }\left(\mathrm{s}^{-1}\right)\end{array}$ & $\begin{array}{c}\text { Time to } \\
\text { Failure }(\mathrm{h})\end{array}$ & $\begin{array}{c}\text { Elongation } \\
(\%)\end{array}$ & $\begin{array}{c}\text { Ultimate } \\
\text { Strength } \\
(\mathrm{MPa})\end{array}$ \\
\hline \multicolumn{5}{c}{ As-received properties } \\
B & $1.02 \mathrm{E}-06$ & 54.8 & 19.8 & 527 \\
C & $1.67 \mathrm{E}-06$ & 36.4 & 21.9 & 512 \\
B & As-welded properties & \\
C & $1.06 \mathrm{E}-06$ & 9.2 & 3.5 & 450 \\
\hline
\end{tabular}

B) Borated water at $150^{\circ} \mathrm{C}$; aerated

C) Air atmosphere at $150^{\circ} \mathrm{C}$

In the electrochemical tests, a wide range of stable 
passivity was observed at a current density of $3 \times 10^{-06}$ $\mathrm{A} / \mathrm{cm}^{2}$ as shown in Figure 1. The calculated corrosion rates were low and are presented in Table 6.

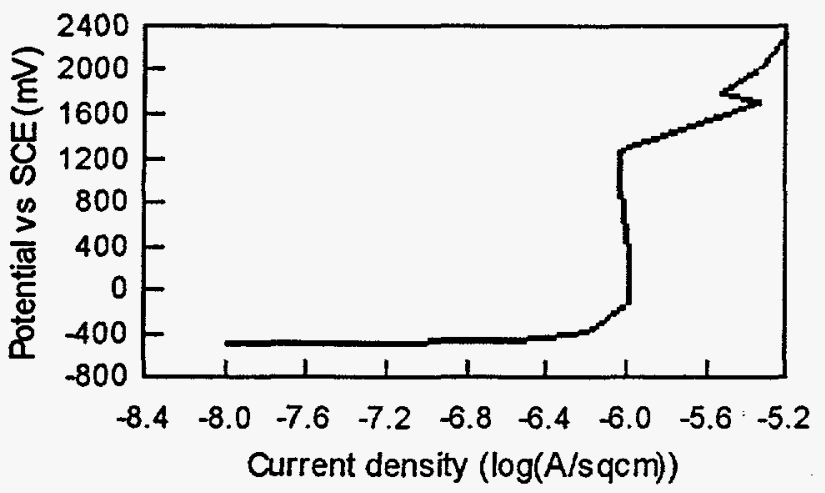

Figure 1. Representative curve for Ti-6Al-4V in ambient borated water.

Table 6. Corrosion rates in mils/yr assuming $+4 /+3$ oxidation states for titanium at temperatures.

\begin{tabular}{lll}
\hline Alloy & Ambient & Boiling \\
\hline Ti-6Al-4V & $0.3 / 0.5$ & $1.0 / 1.4$ \\
$\mathrm{Ti}$ & $0.3 / 0.5$ & $1.0 / 1.4$
\end{tabular}

As shown in Table 7, there was a 200 to $300 \mathrm{mv}$ change in the onset of apparent transpassivity with temperature.

Table 7. Differences between open circuit potential and the onset of apparent transpassivity at temperatures.

\begin{tabular}{lll}
\hline Alloy & Ambient & Boiling \\
\hline Ti-6Al-4V & $1790 \mathrm{mv}$ & $1490 \mathrm{mv}$ \\
$\mathrm{Ti}$ & $1704 \mathrm{mv}$ & $1516 \mathrm{mv}$
\end{tabular}

These tests demonstrated an unusual behavior beyond the apparent transpassive region. From the start of apparent transpassivity $(1350 \mathrm{mv})$ to about $2200 \mathrm{mv}$ versus saturated calomel electrode (SCE), the slope of the voltage/current line is constant at 250 to $350 \mathrm{mv} / \mathrm{dec}$ de of current. At about $2200 \mathrm{mv}$ versus SCE, an apparent secondary passive region occurs at very high current densities ( $1 \times 10^{-4} \mathrm{~A} \mathrm{~cm}^{2}$, boiling; $1 \times 10^{-5.5} \mathrm{~A} \mathrm{~cm}^{2}$, ambient).

\section{DISCUSSION}

\section{Constant Extension Rate Tensile Tests}

Results of the CERT tests showed that immersion in a concentrated boric acid solution at $150^{\circ} \mathrm{C}$ had no effect on the mechanical behavior of either of the Ti-Al-V alloys. There were no adverse effects in terms of percent elongation or gage length appearance for specimens tested in aerated solution versus those tested in deaerated solutions or in air. The percent elongations of these alloys correspond closely to published room temperature tensile test results for alloys made by similar processing and fabrication techniques [1]. The ultimate strength of Ti-6AI$4 \mathrm{~V}$ was approximately 0.8 of its ultimate strength at room temperature (see Table 4). This factor agrees very closely with the percentage loss in ultimate strength reported for Ti-6Al-4V when the temperature is increased from 25 to $150^{\circ} \mathrm{C}$ [2]. Elongations were $11-12 \%$ for Ti-6Al-4V and 20-22\% for Ti-3Al-2.5V. However, welded specimens, except for plate specimens of Ti-6AI-4V, generally exhibited lower elongation to failure as compared to the unwelded specimens. These decreased elongations were not related to the test environment (elongations were no higher in air than in the boric acid solution) but were a result of strength differences between the base metal and the weld fusion zones. The greater strength of the base metal constrained deformation of the gage length to the relatively narrow fusion zone, which, though ductile, failed at a relatively low overall elongation due to its limited volume. In the case of the welded (industrial practice) Ti-6Al-4V plate specimens, the strength of the base metal more closely matched that of the fusion zone, and the elongations at failure approached those of unwelded material. In general, the duration of these CERT tests (1930 hours) were long compared to the cracking induction times associated with materials susceptible to stress corrosion cracking. Thus, it is concluded that Ti-6Al-4V and $\mathrm{Ti}-3 \mathrm{Al}-2.5 \mathrm{~V}$ alloys are immune to stress corrosion cracking in concentrated boric acid at the open circuit potential at $150^{\circ} \mathrm{C}$.

\section{Electrochemical Tests}

At high temperatures, initial attempts at obtaining meaningful measurements using various combinations of Saturated Calomel Electrodes and Luggin probes for reference electrodes produced limited data. The relatively high resistivity of the test solution and the lack of a stable high temperature reference electrode contributed to this difficulty. Long term use of calomel in these solutions, even at moderate temperatures, is compromised by the likelihood of leakage of chlorides from the calomel reference electrode into the test solution. As a result, platinum (Pt) wire was used for a reference electrode in the high temperature solutions. By measuring the potential difference between the platinum and a saturated calomel electrode immersed for only a few seconds in the hot 
solution, a rough correction factor for $\mathrm{Pt}$ relative to the saturated calomel electrode scale could be achieved. It must be emphasized that only under very specific conditions (not achieved in these tests) does a platinum wire function as an invariant reference electrode. However, the variability of the platinum is small compared to the range of potential measurements needed to determine suitability of Ti-6Al-4V for the service environment.

Some potentially important trends were apparent. Ti and Ti-6Al-4V were both passive in this environment over similarly wide potential ranges. This large passive region is larger than the expected MHD induced potentials. Increases in solution temperature from ambient to boiling $\left(104^{\circ} \mathrm{C}\right.$ ) increased the passive current density only about a factor of three. The materials exhibited an apparent transpassive behavior. At some potential (on the order of $1350 \mathrm{mv}$ vs SCE or a little higher), small increases in potential caused substantial current increases. In some alloy/environment combinations, this behavior is indicative of pitting. However, when the materials were held at a potential in this apparent transpassive region, the current density decreased slowly with time; and post-test examination of the rod specimens revealed no pitting or other localized corrosion for any scans (up to $2.8 \mathrm{v}$ vs SCE). In some alloy/environment combinations, the above behavior is indicative of transpassivity of the alloy. Transpassivity is generally associated with an increase in potential that results in a previously insoluble (and protective) film being oxidized to a soluble state. Transpassivity is not typically observed in pure titanium or aluminum, and the similarity of behavior of $\mathrm{Ti}$ and Ti-6Al-4V suggests this behavior is not a result of the vanadium in the alloy. Further, no gas evolved at the electrodes for potentials above the apparent start of transpassivity, indicating oxidation of water (evolving oxygen) was not occurring. Thus, this apparent transpassive behavior is not understood and needs further investigation.

\section{CONCLUSIONS}

1. The same fracture behavior, strengths, and elongations were observed for in CERT testing for unwelded Ti-6Al-4V rod and T-3Al-2.5V tubing in concentrated boric acid at $150^{\circ} \mathrm{C}$ as in air. The ultimate tensile strength in both environments at $150^{\circ} \mathrm{C}$ was 0.8 the value measured at room temperature, and the elongations at fracture at $150^{\circ} \mathrm{C}$ were equivalent to those at room temperature.

2. CERT testing of ORNL welded specimens at $150^{\circ} \mathrm{C}$ showed lower elongations at fracture and lower ultimate tensile strengths as compared to the unwelded specimens. This reduction in properties was due to the weld fusion zone being less strong than the surrounding base metal, and was not a function of the environment.

3. CERT testing of industrially welded plates of Ti- $6 \mathrm{Al}-4 \mathrm{~V}$ showed essentially the same strength and elongation as the unwelded plate. Mechanical properties in air and boric acid were equivalent, and no environmental effects were visible in either the weld fusion or heat affected zones.

4. CERT tests indicated that Ti-6Al-4V and Ti-3Al-2.5V alloys are not subject to stress corrosion cracking at open circuit potential in boric acid at $150^{\circ} \mathrm{C}$.

5. At $104^{\circ} \mathrm{C}$ in boric acid, Ti-6Al-4V exhibited an apparent transpassive behavior between $1350 \mathrm{mv}$ and $2200 \mathrm{mv}$ versus SCE.

6. Above $2200 \mathrm{mv}$, at $104^{\circ} \mathrm{C}$ in boric acid, Ti-6Al-4V exhibited the onset of a secondary passive region at very high current density of $1 \times 10^{-4} \mathrm{~A} / \mathrm{cm}^{2}$.

7. At the applied voltages achieved, at $104^{\circ} \mathrm{C}$ in boric acid, Ti-6Al-4V did not exhibit any signs of localized corrosion.

8. At $104^{\circ} \mathrm{C}$ in boric acid, Ti-6Al-4V exhibited a low corrosion and a large passive region.

\section{REFERENCES}

[1] ASM International Handbook, Vol. 2, p. 637, Oct 1990. [2] MIL-HDBK-5D, p. 5-64, June 1983.

Refer questions to:

D. F. Wilson

Oak Ridge National Laboratory

Metals \& Ceramics Division

P.O. Box 2008

4500-S, MS-6156

Oak Ridge, TN 37831-6156

(423) $576-4810$

(423)-574-5118 (fax)

wilsondf@ornl.gov 


\section{DISCLAIMER}

This report was prepared as an account of work sponsored by an agency of the United States Government. Neither the United States Government nor any agency thereof, nor any of their employees, makes any warranty, express or implied, or assumes any legal liability or responsibility for the accuracy, completeness, or usefulness of any information, apparatus, product, or process disclosed, or represents that its use would not infringe privately owned rights. Reference herein to any specific commercial product, process, or service by trade name, trademark, manufacturer, or otherwise does not necessarily constitute or imply its endorsement, recommendation, or favoring by the United States Government or any agency thereof. The views and opinions of authors expressed herein do not necessarily state or reflect those of the United States Government or any agency thereof. 